\title{
Problematisch alcoholgebruik, een zorg voor de sociaal werker?
}

\author{
Linda Bolier · Els Bransen
}

Published online: 25 August 2020

(C) The Author(s) 2020

Samenvatting Veel sociaal werkers bespreken signalen van problematisch alcoholgebruik met hun cliënten, voelen zich daarin deskundig en werken samen met de verslavingszorg, zo laat een onlangs door ons uitgevoerde inventarisatie zien. Maar dat is misschien een iets te rooskleurig beeld, menen drie betrokken professionals die we lieten reageren op de resultaten. Er zijn al veel stappen gezet, maar er blijkt ook nog veel te winnen: richting structurele samenwerking tussen sociaal werk en verslavingszorg, en een langere beleidscyclus in het gezondheids- en welzijnsveld, zodat kennis, expertise en relaties op het gebied van problematisch alcoholgebruik behouden blijven.

Trefwoorden problematisch alcoholgebruik . preventieve gezondheidszorg · sociaal werk

Problematic alcohol use, a concern for the social worker?

Abstract Many social workers discuss signs of problematic alcohol use with their clients, they feel competent to do so, and they work closely with addiction care, a recent study by the Trimbos Institute shows. Perhaps this paints too rosy a picture of the situation, according to three participating professionals who responded to the results. Many steps have already been taken, but there is still a lot to gain from structural cooperation between social work and addiction care, and a longer policy cycle in the field of healthcare and welfare, in order to retain knowledge, expertise and networks concerning problematic alcohol use.

L. Bolier $(\bowtie) \cdot$ E. Bransen

Trimbos-instituut, Utrecht, Nederland

lbolier@trimbos.nl
Keywords problematic alcohol use $\cdot$ preventive health services $\cdot$ social work

\section{Inleiding}

Alcohol speelt vaak een rol in problemen waar sociaal werkers mee te maken krijgen, zoals bij schulden, opvoedingsvragen of huiselijk geweld. In 2015 gingen we na in hoeverre sociale wijkteams met alcoholproblematiek te maken krijgen en hoe zij hier een (grotere) rol bij zouden kunnen spelen. De wijkteams deden nog weinig met problematisch alcoholgebruik. Ontbrekende samenwerking met de verslavingszorg, en geringe kennis en vaardigheden op dit gebied waren hier debet aan [1]. Drie jaar na onze eerste inventarisatie gingen wij opnieuw na welke rol sociaal werkers (kunnen) spelen bij de preventie en zorg op het gebied van problematisch alcoholgebruik en verslaving [2].

\section{Toename alcoholalertheid in het sociaal werk?}

In april, mei en juni 2019 stuurden we een online enquête rond via onze website en het netwerk van brancheorganisatie Sociaal Werk Nederland. Ook Verslavingskunde Nederland bracht de enquête bij haar leden onder de aandacht. In totaal vulden 236 sociaal werkers de vragenlijst in, onder wie 41 jongerenwerkers en 113 individueel of op systeemniveau werkende professionals (dit zijn wijkteammedewerkers en maatschappelijk medewerkers over wie we nu vooral rapporteren).

Veel van deze sociaal werkers brengen bij cliënten alcoholgebruik ter sprake: 35\% doet dit bij (bijna) iedereen en $24 \%$ doet dit bij de helft van de cliënten. Meestal gebeurt dit wanneer hun cliënt problemen heeft die kunnen samenhangen met problematisch alcoholgebruik, zoals schulden en huiselijk geweld. 
Nog lang niet altijd is alcoholgebruik een standaardvraag bij de intake (bij slechts $32 \%$ ), maar wel zijn bepaalde signalen van problematisch alcoholgebruik (bijvoorbeeld een alcoholgeur of dronkenschap) voor twee derde (67\%) van de professionals aanleiding om hiernaar te vragen. Van een grote handelingsverlegenheid lijkt dus geen sprake te zijn. Dit is een opmerkelijke bevinding, zeker in vergelijking met de uitkomsten van de eerdere inventarisatie. Hoe kijkt een aantal bij wijkteams betrokken professionals (zie het kader) hier tegenaan?

\section{'Sociaal werker weet dondersgoed waar die van is'}

'Dat is heel mooi dat sociaal werkers zich bewust zijn van alcoholproblematiek en daar ook naar handelen', reageert Johan Huttinga, senior beleidsadviseur preventie bij Sociaal Werk Nederland. 'De verwachtingen van het sociaal werk en de wijkteams zijn groot. Door de veelheid aan issues waar ze aandacht aan moeten geven, zoals eenzaamheid of langer thuis, kan het zomaar gebeuren dat signalen zoals alcoholmisbruik gemist worden. Maar de sociaal werker weet dus dondersgoed waar die van is en neemt zijn verantwoordelijkheid.'

Leidinggevende in de verslavingspreventie Ursula Dewkalie zet enkele kanttekeningen: 'Wij worden als verslavingspreventie nog vooral eenmalig ingeschakeld, als er iets aan de hand is.' Ook zet Dewkalie vraagtekens bij de representativiteit van de steekproef: 'Zou het kunnen zijn dat vooral sociaal werkers die zich al met het thema bezighouden hebben gereageerd? Misschien is het beeld dat uit de inventarisatie komt dan wel iets te positief.'

\section{Signaleren niet vanzelfsprekend}

De professionals die we lieten reageren vinden dat het signaleren van problematisch alcoholgebruik hoort bij de taken van sociaal werkers, maar dat dit in de praktijk niet altijd vanzelfsprekend ook zo gaat. Denise van Kesteren, teamcoach van Jeugd- en Gezinsteams in de Leidse regio, vertelt dat alcoholproblematiek niet vaak op tafel komt: 'Weinig volwassen cliënten zullen hier direct mee komen: vaak zit het achter de problematiek, maar presenteert het zich niet zo. En als het jeugd betreft zien we dat veel ouders het ontkennen of het gebruik bagatelliseren.'

Dit beeld correspondeert met de resultaten uit de meest recente peiling van Movisie naar de stand van zaken rond sociale wijkteams in Nederlandse gemeenten [3]. In deze vierde peiling (de eerste was in 2015) is op verzoek van het Trimbos-instituut voor het eerst een aantal vragen over problematisch middelengebruik en verslaving opgenomen. Het merendeel (64\%) van de 157 ondervraagde gemeenten geeft aan dat de wijkteams zelf geen vragen rond dit thema oppakken, maar dat 'zij gebruikmaken van externe specialisten in de verslavingszorg'. Slechts $20 \%$ van de gemeenten geeft aan dat een of meer medewerkers in het wijkteam deskundig zijn op het terrein van problematisch middelengebruik en verslaving.

Ursula Dewkalie herkent dit beeld en mist daarbij vooral de preventieve zorg: 'We worden er vooral bijgehaald als er incidenten of al grote problemen zijn. Preventief werken in de wijkteams, met hulp van onze expertise, vindt nog niet op structurele basis plaats.'

\section{Verschillende soorten wijkteams}

Of alcoholproblematiek op tafel komt door de cliënt zelf of ter sprake wordt gebracht door de professional, zal ook afhangen van het soort wijkteam. Er zijn bijvoorbeeld wijkteams die meer op de toegang naar de Wmo-voorzieningen zitten, en er zijn wijkteams die veel meer op cliëntondersteuning en hulpverlening zitten. 'Dat bepaalt je klantenbestand en scope', zegt Johan Huttinga, 'In het tweede geval kijk je eerder naar alcoholproblematiek en zoek je de samenwerking met de verslavingszorg.' Ursula Dewkalie ervaart belemmeringen door de wijze waarop de wijkteams in haar regio zijn ingericht: 'Cliënten komen pas bij een wijkteam met problemen nadat ze zichzelf gemeld hebben bij een servicebalie van de gemeente. Dat is natuurlijk al een grote drempel, en ze zullen zelf niet zo snel beginnen over hun middelengebruik.'

\section{Kennis en expertise borgen}

Uit de inventarisatie blijkt verder dat wijkteams volgens de meeste respondenten $(72 \%)$ geen directe expertise hebben op het gebied van problematisch alcoholgebruik. Daar staat tegenover dat 50 tot $60 \%$ wel gebruikmaakt van de voorzieningen die de verslavingszorg biedt, zoals informatie op de website of de mogelijkheid van consultatie. Het lijkt ook niet realistisch dat in ieder wijkteam een professional uit de verslavingskunde gestationeerd is. 'Ik kan niet in ieder wijkteam iemand neerzetten,' aldus Dewkalie, 'maar we zouden in de verslavingspreventie kunnen gaan werken met vaste contactpersonen die de wijkteams deskundigheid geven, en die altijd geraadpleegd kunnen worden voor advies.'

Zo werken ze in de wijkteams van Denise Van Kesteren: 'We hebben een goede samenwerking met de Brijder Verslavingszorg en -preventie. Zij bieden scholing aan en ieder jaar is er een groep in het wijkteam die getraind wordt. Zo verspreidt de kennis zich binnen ons team.' Ook is er in dit wijkteam een collega die zich wat meer wil gaan specialiseren in de verslavingszorg. 'Zij krijgt extra scholing en ruimte hiervoor', aldus Van Kesteren.

\section{De toekomst}

Wat vinden onze geïnterviewden belangrijk voor de toekomst? Vinden ze het net als wij belangrijk dat 


\section{Wie interviewden we?}

We spraken met drie betrokkenen uit het sociaal werk, en lieten hen reageren op de resultaten van de inventarisatie:

- Ursula Dewkalie - leidinggevende bij Indigo Haaglanden, onderdeel van de Parnassiagroep. Zoekt aansluiting bij de 17 sociale wijkteams in Haaglanden. Is actief binnen het samenwerkingsverband Verslavingskunde Nederland.

- Denise van Kesteren - teamcoach van Jeugd- en Gezinsteams bij coöperatie JGt Holland Rijnland in de Leidse regio. Werkt wat betreft preventie en behandeling actief samen met de verslavingszorg.

- Johan Huttinga - senior beleidsmedewerker preventie bij Sociaal Werk Nederland. Is blij verrast met de positieve uitkomsten van de enquête, maar ziet ook nog veel mogelijkheden voor verbetering.

sociaalwerkorganisaties investeren in een structurele samenwerking met de verslavingszorg? Hechten ze ook aan deskundigheidsbevordering als vast onderdeel van de scholing voor sociaal werkers? Dat blijkt zeker het geval, en daarnaast doen ze nog wat eigen aanbevelingen.

'Samenwerking' is een veelgehoord sleutelwoord in de ideeën die de geïnterviewden geven. Professionals uit de verslavingspreventie kunnen bijvoorbeeld adviseren hoe een ketenaanpak bij problematisch alcoholgebruik kan worden vormgegeven. 'We hebben hier veel expertise in en een groot netwerk', zegt Dewkalie. In een ketenaanpak werken alle partners die bij een probleem betrokken zijn op een samenhangende wijze en met een duidelijk doel samen, onder regie van één partij. Huttinga beaamt dit: 'Het sociaal werk en de wijkteams zouden zich meer kunnen presenteren vanuit netwerken, en minder vanuit de verschillende organisaties. Dus ook alcoholgebruik moeten we als netwerk aanpakken, samen met huisarts, gemeente, enzovoort. En het probleem aanpakken per buurt, op wijkniveau.'

Een lastig punt dat uit de inventarisatie naar voren kwam is dat cliënten vaak zelf niet inzien dat er sprake is van een alcoholprobleem. Ook schamen cliënten zich of zijn ze bang om erover te praten als er jonge kinderen in het gezin zijn. Het onderwerp zou standaard onderdeel gemaakt kunnen worden van de veiligheidsafpraken die je met een gezin maakt, oppert Denise van Kesteren. 'Bijvoorbeeld in een gezin waar vader drinkt en agressief kan zijn, maak je met de moeder een afspraak dat ze naar de buurvrouw gaat om zichzelf en de kinderen veilig te stellen. Vader motiveren we om hulp te zoeken. Dit zetten we zwart-op-wit.'
Een aantal sociaal werkers benoemde in de inventarisatie als knelpunt dat de samenwerking met de verslavingszorg in hun regio nog tekortschiet. Johan Huttinga ziet hierin een duidelijke voortrekkersrol voor het sociaal werk: 'We moeten ervoor zorgen dat welzijn en de wijkteams goed met elkaar samenwerken, en de andere partners, zoals de verslavingszorg, hierbij betrekken. Dan kom je pas goed aan preventie toe: problemen voorkómen, mensen die elkaar gaan ondersteunen en zelfredzaam zijn.'

En Huttinga doet er nog een schepje bovenop: hij vindt dat de sociaal werker veel meer de rol en functie zou kunnen pakken om de gemeente te adviseren. Ook zou het in zijn ogen beter zijn als de aanbestedingen van de gemeenten voor sociaal werk een langere cyclus (van bijvoorbeeld vier jaar) zouden behelzen: 'Telkens voor één jaar aanbesteden staat een goede kennisontwikkeling en samenwerking, bijvoorbeeld met de verslavingszorg, in de weg.'

\section{Conclusie}

Uit een recente inventarisatie bleek dat sociaal werkers alcoholgebruik geregeld ter sprake brengen bij hun cliënten, zich deskundig voelen op het gebied van alcoholproblematiek en vaak samenwerken met professionals in de verslavingszorg [2]. Een peiling van Movisie uit hetzelfde jaar laat een wat ander beeld zien (bijvoorbeeld maar $20 \%$ van de wijkteams heeft een lid dat deskundig is in de materie) en ook onze geïnterviewden geven aan dat er nog een wereld te winnen is [3]. Dit verschil in resultaat kan mogelijk te maken hebben met de representativiteit van onze steekproef: slechts een klein deel van alle sociaal werkers in Nederland (236 op een populatie van $>50.000$ ) heeft de vragenlijst in gevuld. Daarnaast kan het verschil in resultaat komen door de verschillen in opzet van wijkteams. Duidelijk is dat de geïnterviewden vinden dat er in ieder geval flinke stappen moeten worden gezet:

- naar een betere en structurele samenwerking tussen sociaal werk en verslavingszorg, waarin niet alleen bij incidenten met elkaar wordt overlegd, en waarin niet vanuit de organisaties, maar vanuit netwerken bij een bepaald probleem wordt gedacht;

- waar met het welzijnsveld wordt samengewerkt, en waar mensen aangesproken worden vanuit hun eigen krachten en mogelijkheden tot eigen regie;

- naar een langere beleidscyclus in het welzijns- en gezondheidsveld, zodat kennis over problematisch alcoholgebruik meer kans krijgt geborgd te worden binnen de wijkteams en het welzijnsveld, en de samenwerkingsverbanden die gelegd worden van structurele aard kunnen zijn.

Open Access This article is licensed under a Creative Commons Attribution 4.0 International License, which permits use, sharing, adaptation, distribution and reproduction in any medium or format, as long as you give appropriate credit 
to the original author(s) and the source, provide a link to the Creative Commons licence, and indicate if changes were made. The images or other third party material in this article are included in the article's Creative Commons licence, unless indicated otherwise in a credit line to the material. If material is not included in the article's Creative Commons licence and your intended use is not permitted by statutory regulation or exceeds the permitted use, you will need to obtain permission directly from the copyright holder. To view a copy of this licence, visit http://creativecommons.org/licenses/by/4.0/.

\section{Literatuur}

1. Bransen E, Collard P, Poel A van der. Sociale (wijk)teams en verslavingspreventie: kansen en belemmeringen. Verslaving. 2016;12(4):289-92.

2. Bolier L, Conijn B, Doesum T van, Bransen E. Sociaal werker helpt mee alcoholproblematiek terug te dringen. Een inventarisatie van ervaringen en knelpunten. Vakbl Sociaal Werk. 2019;5:19-22.

3. Arum S van, Broekroelofs R, Xanten $\mathrm{H}$ van. Sociale (wijk)teams: vijf jaar later. Vierde landelijke peiling onder Nederlandse gemeenten (zomer 2019). Utrecht: Movisie; 2020. 